\title{
RP4:: Mu3A-mediated in vivo cloning and transfer of a chlorobiphenyl catabolic pathway
}

\author{
Dirk Springael, ${ }^{1}$ Jasper van Thor, ${ }^{2}$ Heleen Goorissen, ${ }^{2}$ \\ Annemie Ryngaert, ${ }^{1}$ Raymond De Baere, ${ }^{3}$ Peter Van Hauwe, ${ }^{3}$ \\ Laetitia C. M. Commandeur, ${ }^{2}$ John R. Parsons, ${ }^{2}$ Rupert De Wachter ${ }^{3}$ \\ and Max Mergeay ${ }^{1}$

\begin{abstract}
Author for correspondence: Max Mergeay. Tel: +32143351 06. Fax: +3214320372.
\end{abstract} \\ e-mail: mergeaym@vito.be
}

\author{
1 Environmental \\ Technology, Flemish \\ Institute for Technological \\ Research (VITO), \\ Boeretang 200, B-2400 \\ Mol, Belgium \\ 2 Department of \\ Environmental and \\ Toxicological Chemistry, \\ University of Amsterdam, \\ Nieuwe Achtergracht 166, \\ $\mathrm{N}-1018$ WV Amsterdam, \\ The Netherlands \\ 3 Department of \\ Biochemistry, University of \\ Antwerp (UIA). \\ Universiteitsplein 1, B-2610 \\ Antwerpen, Belgium
}

\begin{abstract}
Chromosomal DNA fragments encoding the ability to utilize biphenyl as sole carbon source (Bph+) were mobilized by means of plasmid RP4::Mu3A from strain JB1 (tentatively identified as Burkho/deria sp.) to Alcaligenes eutrophus CH34 at a frequency of $10^{-8}$ per transferred plasmid. The mobilized DNA integrated into the recipient chromosome or was recovered as catabolic prime plasmids. Three Bph ${ }^{+}$prime plasmids were transferred from A. eutrophus to Escherichia coli and back to A. eutrophus without modification of the phenotype. The transferred Bph+ DNA segments allowed metabolism of biphenyl, 2-, 3- and 4-chlorobiphenyl, and diphenylmethane. Genes involved in biphenyl degradation were identified on the prime plasmids by DNA-DNA hybridization and by gene cloning. Bph+ prime plasmids were transferred to Burkholderia cepacia, Pseudomonas aeruginosa, Comamonas testosteroni and A. eutrophus and the catabolic genes were expressed in those hosts. Transfer of the plasmid to the 3-chlorobenzoate-degrading bacterium Pseudomonas sp. B13 allowed the recipient to mineralize 3-chlorobiphenyl. Other catabolic prime plasmids were obtained from JB1 by selection on $\boldsymbol{m}$-hydroxybenzoate and tyrosine as carbon sources. 165 rRNA sequence data demonstrated that the in vivo transfer of bph was achieved between bacteria belonging to two different branches of the $\beta$-Proteobacteria.
\end{abstract}

Keywords: chlorobiphenyl catabolism, $\beta$-Proteobacteria, in vivo cloning and transfer, RP4::Mu3A

\section{INTRODUCTION}

Genetic studies of aerobic PCB degradation by bacteria have focused on the cloning and characterization of the degradative pathway genes in a variety of bacteria (Ahmad et al., 1990; Asturias \& Timmis, 1993; Furukawa \& Miyazaki, 1986; Khan \& Walia, 1989; Kimbara et al., 1989; Mondello, 1989; Peloquin \& Greer, 1993; Taira et al., 1992). These studies provide a good basis for an evolutionary comparison between the genes involved in

\footnotetext{
Abbreviations: $\mathrm{PCB}$, polychlorinated biphenyl; BP, biphenyl; $\mathrm{CBP}$, chlorinated biphenyl; 2CBP, 2-chlorobiphenyl; 3CBP, 3-chlorobiphenyl; 4CBP, 4chlorobiphenyl; 3CBA, 3-chlorobenzoate; 4CBA, 4-chlorobenzoate; 2CBA, 2-chlorobenzoate.

The GenBank accession number for the sequence of 16S rRNA of strain JB1 is $\mathrm{X} 92188$.
}

the individual steps of BP degradation in different $\mathrm{PCB}$ degraders and between the various patterns of gene organization or clustering observed. Horizontal gene transfer may be suspected as one of the driving forces in rearranging the genes in the various $b p h$ clusters and in the subsequent adaptation of a microbial community to the availability of new potential substrates such as PCBs.

In most PCB-degrading bacterial strains the PCB catabolic genes are chromosomally located (Ahmad et al., 1990; Asturias \& Timmis, 1993; Furukawa et al., 1989; Hayase et al., 1990; Mondello, 1989). There is some evidence that these genes have been transferred between bacteria. Furukawa et al. (1989) demonstrated by DNA-DNA hybridization the occurrence of similar $b p h A B C D$ gene cassettes in PCB-degrading bacteria of different origins. Transfer of PCB catabolic genes has been demonstrated between Rhodococcus globerulus $\mathrm{P} 6$ and Pseudomonas sp. HF1 
Table 1. Bacterial strains and plasmids

\begin{tabular}{|c|c|c|c|c|}
\hline Strains & & $\begin{array}{l}\text { Plasmids and relevant } \\
\text { markers* }\end{array}$ & $\begin{array}{c}\text { Relevant chromosomal } \\
\text { markers* }\end{array}$ & Reference or source \\
\hline \multicolumn{5}{|l|}{ Burkholderia sp. } \\
\hline JB1 & & - & $\begin{array}{l}\mathrm{Bph}^{+} 2 \mathrm{Cbp}^{+} 3 \mathrm{Cbp}^{+} 4 \mathrm{Cbp}^{+} \\
\mathrm{Mtol}^{+} \mathrm{Ptol}^{+} \mathrm{Nah}^{+} \mathrm{Mhb}^{+} \\
\mathrm{Dpm}^{+}\end{array}$ & Parsons et al. (1988) \\
\hline AE1185 & & $\mathrm{RP} 4:: \mathrm{Mu} 3 \mathrm{~A}\left(\mathrm{Tc}^{\mathrm{r}} \mathrm{Ap^{r }} \mathrm{Km}^{\mathrm{r}}\right)$ & $\begin{array}{l}\mathrm{Bph}^{+} 2 \mathrm{Cbp}^{+} 3 \mathrm{Cbp}^{+} 4 \mathrm{Cbp}^{+} \\
\mathrm{Mtol}^{+} \mathrm{Ptol}^{+} \mathrm{Nah}^{+} \mathrm{Mhb}^{+} \\
\mathrm{Dpm}^{+}\end{array}$ & This study \\
\hline AE1236 & & $\mathrm{RP} 4\left(T c^{r} A p^{r} K m^{r}\right)$ & $\begin{array}{l}\mathrm{Bph}^{+} 2 \mathrm{Cbp}^{+} 3 \mathrm{Cbp}^{+} 4 \mathrm{Cbp}^{+} \\
\mathrm{Mtol}^{+} \mathrm{Ptol}^{+} \mathrm{Nah}^{+} \mathrm{Mhb}^{+} \\
\mathrm{Dpm}^{+}\end{array}$ & This study \\
\hline \multicolumn{5}{|l|}{ A. eutrophus } \\
\hline $\mathrm{CH} 34$ & & $\begin{array}{l}\text { pMOL28 }\left(\mathrm{Nic}^{+}\right), \text {pMOL30 } \\
\left(\mathrm{Zin}^{+}\right)\end{array}$ & - & Mergeay et al. (1985) \\
\hline AE53 & & $\begin{array}{l}\text { pMOL28 } \\
\left(\mathrm{Zin}^{+}\right)\end{array}$ & lys -53 & Sadouk \& Mergeay (1993) \\
\hline AE7 & & $\begin{array}{l}\text { pMOL28 }\left(\mathrm{Nic}^{+}\right), \text {pMOL30 } \\
\left(\mathrm{Zin}^{+}\right)\end{array}$ & tyuB7 ntr-7 & Sadouk \& Mergeay (1993) \\
\hline AE992 & & $\begin{array}{l}\text { pMOL } 28\left(\mathrm{Nic}^{+}\right), \text {pMOL30 } \\
\left(\mathrm{Zin}^{+}\right), \mathrm{pSSD} 51 b p b 1\end{array}$ & - & D. Springael \\
\hline \multicolumn{5}{|l|}{ E. coli } \\
\hline CM214 & & $\mathrm{RP} 4:: \mathrm{Mu} 3 \mathrm{~A}\left(\mathrm{Tc}^{\mathrm{r}} \mathrm{Ap}^{\mathrm{r}} \mathrm{Km}^{\mathrm{r}}\right)$ & $\mathrm{F}^{-} \Delta(l a c-p r o)$ thi $A \operatorname{rec} A$ galE & Lejeune et al. (1983) \\
\hline CM330 & & - & $\begin{array}{l}\text { met-803 gal bsdR bsdM } M^{+} \text {supE } \\
(\mathrm{BHB} 2600)\end{array}$ & Springael et al. (1993b) \\
\hline CM844 & & $\begin{array}{l}\mathrm{RP} 4:: \operatorname{Tn} 4371\left(\mathrm{Tc}^{\mathrm{r}} \mathrm{Ap}^{\mathrm{r}} \mathrm{Km}^{\mathrm{r}}\right. \\
\left.\mathrm{Bph}^{+} 4 \mathrm{Cbp}^{+}\right)\end{array}$ & $\begin{array}{l}\text { met-803 gal bsdR bsdM supE } \\
\operatorname{supF}(\mathrm{BHB} 2600)\end{array}$ & Springael et al. (1993b) \\
\hline CM1073 & & $\begin{array}{c}\mathrm{R}-b p b 1\left(\mathrm{Tc}^{\mathrm{r}} \mathrm{Ap}^{\mathrm{r}} \mathrm{Km}^{\mathrm{r}} \mathrm{Bph}^{+}\right. \\
\left.4 \mathrm{Cbp}^{+} 3 \mathrm{Cbp}^{+} 2 \mathrm{Cbp}^{+} \mathrm{Dpm}^{+}\right)\end{array}$ & $\begin{array}{l}\text { met-803 gal hsdR bsdM } \\
\text { sup Esup F (BHB2600) }\end{array}$ & This study \\
\hline CM1074 & & $\begin{array}{c}\mathrm{R}-b p h 2\left(\mathrm{Tc}^{\mathrm{r}} \mathrm{Ap}^{\mathrm{r}} \mathrm{Km}^{\mathrm{r}} \mathrm{Bph}^{+}\right. \\
\left.4 \mathrm{Cbp}^{+} 3 \mathrm{Cbp}^{+} 2 \mathrm{Cbp}^{+} \mathrm{Dpm}^{+}\right)\end{array}$ & $\begin{array}{l}\text { met-803 gal bsdR bsdM } M^{+} \text {supE } \\
\text { supF } r p s L^{+}(\mathrm{BHB} 2600)\end{array}$ & This study \\
\hline CM1168 & & $\begin{array}{c}\mathrm{R}-b p h 3\left(\mathrm{Tc}^{\mathrm{r}} \mathrm{Ap}^{\mathrm{r}} \mathrm{Km}^{\mathrm{r}} \mathrm{Bph}^{+}\right. \\
\left.4 \mathrm{Cbp}^{+} 3 \mathrm{Cbp}^{+} 2 \mathrm{Cbp}^{+} \mathrm{Dpm}^{+}\right)\end{array}$ & $\begin{array}{l}\text { met-803 gal bsdR bsdM } M^{+} \sup E \\
\operatorname{supF}(\mathrm{BHB} 2600)\end{array}$ & This study \\
\hline CM887 & & $\mathrm{pRK} 415\left(\mathrm{Tc}^{\mathrm{r}}\right)$ & $\mathrm{S} 17 / 1$ & Keen et al. (1988) \\
\hline DH10B & & r & $\begin{array}{l}\mathrm{F}^{-} \text {mcr } A \Delta(m r r-b s d \mathrm{R} M S \\
-m c r B C) \phi 80 \operatorname{dac} Z \Delta M 15 \\
\Delta l a c X 74 \operatorname{deo} \mathrm{R} \operatorname{rec} A 1 \text { end } A 1 \\
\text { araD139 } \Delta a r a, \text { leu } 7697, \text { galU }) \\
\text { galK } \lambda^{-} \text {rpsL nupG }\end{array}$ & GIBCO BRL \\
\hline A. eutropbus & ATCC 17697 & - & - & - \\
\hline A. eutrophus & $\mathrm{H} 16$ & pHG1 $\left(\mathrm{Hox}^{+} \mathrm{Cfx}^{+}\right)$ & - & Steinbüchel et al. (1983) \\
\hline A. eutropbus & JMP222 & - & - & Don \& Pemberton (1981) \\
\hline B. cepacia & $\mathrm{JH} 230$ & - & $\begin{array}{l}2 \mathrm{Cba}^{+} 3 \mathrm{Cba}^{+} 4 \mathrm{Cba} 3,4 \mathrm{Cba}^{+} \\
2,5 \mathrm{Cba}^{+}\end{array}$ & Havel \& Reineke (1991) \\
\hline B. cepacia & ATCC 17816 & - & - & - \\
\hline A. autotropbicum & ATCC 29984 & - & - & - \\
\hline C. testosteroni & ATCC 11936 & - & - & - \\
\hline R. meliloti & $\mathrm{B} 23$ & - & - & - \\
\hline$P$. aeruginosa & $\mathrm{JB} 2$ & - & $2 \mathrm{Cba}^{+} 3 \mathrm{Cba}^{+} 2,3 \mathrm{Cba}^{+} 2,5 \mathrm{Cba}^{+}$ & Hickey \& Focht (1990) \\
\hline$P$. aeruginosa & 7 NSK2 & - & - & Höfte et al. (1990) \\
\hline P. putida & PaW1 & pWW0 $\left(\mathrm{Tol}^{+} \mathrm{Xyl}^{+}\right)$ & - & Assinder \& Williams (1990) \\
\hline P. putida & ATCC 12633 & - & - & - \\
\hline P. fluorescens & XO150 & - & - & - \\
\hline A. calcoaceticus & ATCC 10153 & - & - & - \\
\hline$X$. maltophilia & ATCC 13637 & - & - & - \\
\hline Pseudomonas sp. & $\mathrm{B} 13$ & $\mathrm{pB} 13\left(3 \mathrm{Cba}^{+}\right)$ & - & Dorn et al. (1974) \\
\hline
\end{tabular}

* Phenotypes: $\mathrm{Bph}^{+}, 4 \mathrm{Cbp}^{+}, 2 \mathrm{Cbp}^{+}, 3 \mathrm{Cbp}^{+}, \mathrm{Mtol}^{+}, \mathrm{Ptol}^{+}, \mathrm{Nah}^{+}, \mathrm{Mhb}^{+}, \mathrm{Dpm}^{+}, 2 \mathrm{Cba}^{+}, 3 \mathrm{Cba}^{+}, 4 \mathrm{Cba}^{+}, 2,5 \mathrm{Cba}^{+}, 3,4 \mathrm{Cba}^{+}, 2,3 \mathrm{Cba}^{+}, \mathrm{Xyl}^{+}, \mathrm{Tol}^{+}$, abilities to utilize BP, 4CBP, 2 CBP, 3CBP, $m$-toluate, $p$-toluate naphthalene, $m$-hydroxybenzoate; diphenylmethane, $2 \mathrm{CBA}, 3 \mathrm{CBA}, 4 \mathrm{CBA}, 2,5$ dichlorobenzoate, 3,4-dichlorobenzoate, 2,3-dichlorobenzoate, xylene and toluene as carbon sources, respectively; $\mathrm{Zin}^{+}$, Nic ${ }^{+}$, resistance to zinc and nickel; $\mathrm{Tc}^{\mathrm{r}}, \mathrm{Km}^{\mathrm{r}}, \mathrm{Ap}^{\mathrm{r}}$, resistance to tetracycline, kanamycin and ampicillin, respectively; Hox ${ }^{+}$, ability to oxidize molecular hydrogen; $\mathrm{Cfx}^{+}$, ability to fix carbon dioxide autotrophically. 
(Adams et al., 1992), between Artbrobacter sp. B1Barc and Pseudomonas aeruginosa HF1 (Hickey et al., 1992), between Pseudomonas putida JHR and Burkholderia cepacia JH230 (Havel \& Reineke, 1991), and between P. putida BN10 and Pseudomonas sp. B13 (Mokross et al., 1990), but the genetic mechanisms involved were not reported. Other reports have described the involvement of plasmids in PCB metabolism (Selifonov \& Starovoitov, 1991; Carrington et al., 1994; Lloyd-Jones et al., 1994). Recently, we identified and described Tn4371, a PCB catabolic transposable element in Alcaligenes eutrophus, which can be transferred by means of broad-host-range plasmids to other bacterial species (Springael et al., 1993a, b).

Plasmids carrying transposons, such as RP4::Mu3A, R18.18 and R68.45, can mobilize large chromosomal DNA fragments and form prime plasmids (Haas \& Holloway, 1976; Haas \& Reimann, 1989; Lejeune et al., 1983; Van Gijsegem \& Toussaint, 1982). So far, this technique has mainly been used to complement mutations in the recipient strain (Haas \& Reimann, 1989; Van Gijsegem et al., 1987) and to do chromosomal mapping. Recently, it was used for in vivo cloning and transfer of aromatic catabolic genes. Zhang \& Holloway (1992) used R68.45 to clone a chromosomal region of $P$. aeruginosa specifying the catechol ortho-cleavage pathway by complementation of a cat $A$ mutant of $P$. aeruginosa. Prime plasmid formation was also shown between plasmid R68.45 and a plasmid-encoded phenol catabolic pathway from $P$. putida (Herrmann et al., 1988).

The aim of this study was to investigate whether chromosomally located catabolic pathways could be transferred by means of prime plasmid formation from a donor bacterium to a recipient, thereby introducing a completely new catabolic phenotype into the recipient strain. PCB catabolic genes have been found to be clustered and as such should be amenable to in vivo cloning. The degree of phylogenetic relationship between the donor (strain JB1) and the recipient ( $A$. eutrophus strain $\mathrm{CH} 34$ ) was estimated by $16 \mathrm{~S}$ rRNA sequence analysis.

\section{METHODS}

Bacterial strains, plasmids, media and culture conditions. Strains and plasmids used in this study are listed in Table 1. Strain JB1 was originally isolated from garden soil by its ability to utilize BP, $2 \mathrm{CBP}, 3 \mathrm{CBP}$ and $4 \mathrm{CBP}$ as sole sources of carbon and energy (Parsons et al., 1988). The CBPs are metabolized into their corresponding chlorinated benzoic acids following the BP meta-cleavage pathway.

Strain JB1 was able to grow on other aromatic compounds including $m$ - and $p$-toluate, naphthalene, diphenylmethane, benzoate, and $m$ - and $p$-hydroxybenzoate, and cometabolized higher chlorinated PCBs and chlorinated dioxins (Parsons et al., 1988, 1990; Parsons \& Storms, 1989). AE1185 is a derivative of strain JB1 into which the IncP1 plasmid RP4::Mu3A was introduced. RP4::Mu3A contains the deleted prophage Mu3A, which acts as a transposon and displays $\mathrm{Cma}^{+}$(chromosome mobilizing activity) and the ability to form plasmid primes
(Lejeune et al., 1983; Van Gijsegem \& Toussaint, 1982; Van Gijsegem et al., 1987).

Tris medium (Mergeay et al., 1985) was used as a minimal medium, supplemented with the appropriate carbon source $(0.5 \%$ glucose or lactate; $3 \mathrm{mM}$ benzoate, $m$ - and $p$ - toluate or chlorinated benzoates). BP, CBPs and naphthalene were supplied as crystals. Heavy metals $\left(1 \mathrm{mM} \mathrm{NiCl}_{2}\right.$ and $2 \mathrm{mM} \mathrm{ZnSO}_{4}$ ) and the required amino acids were supplemented as described (Mergeay et al., 1985). Chloride-free minimal medium was prepared as described by Dorn et al. (1974). LB was used as a rich medium. The antibiotics tetracycline, kanamycin and ampicillin were used at concentrations of 20,50 and $50 \mu \mathrm{g} \mathrm{ml}^{-1}$, respectively. All strains were grown at $30^{\circ} \mathrm{C}$.

Matings for plasmid transfer. Plate matings were done as described by Lejeune et al. (1983). All strains were grown on LB at $30^{\circ} \mathrm{C}$.

DNA-DNA hybridization. Southern blot hybridization (Dupont, NEN Research Products) was performed at $65^{\circ} \mathrm{C}$ according to the recommendations of the manufacturer. The $b p b C D$ gene probe was a $1.4 \mathrm{~kb}$ Pst $-X b a \mathrm{I}$ DNA fragment containing the complete $b p b C$ gene and part of the $b p b D$ gene of the PCB catabolic transposon Tn4371 of $A$. eutropbus A5 (De Wilde et al., 1992; Springael et al., 1993b). The $b p h A 1$ gene probe was a $600 \mathrm{bp}$ DNA fragment containing part of the $b p h A 1$ gene (encoding biphenyl dioxygenase) of Pseudomonas fluorescens GS15. This 600 bp DNA fragment was generated by PCR using total DNA of the BP/4CBP-degrading strain $P$. fuorescens GS15 as template. The primers were designed on the basis of the $b p h A 1$ sequence of Pseudomonas pseudoalcaligenes KF707 (Taira et al., 1992). The sequences of the PCR primers were 5'-CAATCAAAGAAGTGCAGGGA-3', corresponding to nucleotides $511-530$ of the KF707 sequence, and $5^{\prime}$ TGCACGGAATCACCCACTTC-3', corresponding to nucleotides 1153-1134. The PCR reaction was performed in 30 cycles, which consisted of a denaturation step of $1 \mathrm{~min}$ at $94^{\circ} \mathrm{C}$, a primer annealing step of $1 \mathrm{~min}$ at $60^{\circ} \mathrm{C}$ and a primer extension step of $2 \mathrm{~min}$ at $70^{\circ} \mathrm{C}$. DNA fragments were purified from agarose using the Gene Clean II purification kit (BIO101). DNA labelling was carried out with a Multiprime labelling reagent kit (Amersham) with ${ }^{32} \mathrm{P}$-labelled dCTP.

DNA preparations and gene cloning. Crude preparations of plasmid DNA were obtained as described by Kado \& Liu (1989). Plasmid extractions for restriction enzyme digestion were done from Escherichia coli as described by Ish-Horowicz \& Burke (1981). Total genomic DNA was isolated as described by Bron \& Venema (1972). Restriction endonuclease analysis were done according to the manufacturer's recommendations (BRL). Cloning into plasmid vector pRK415 (Keen et al., 1988) was performed by mixing $100 \mathrm{ng}$ agarose-purified DNA fragment, $50 \mathrm{ng}$ alkaline-phosphatase-treated PstI-restricted pRK415 DNA, 1 U ligase enzyme (Pharmacia) and $2 \mu \mathrm{l} 5 \times$ ligase buffer in a total volume of $10 \mu \mathrm{l}$, and by incubating the mixture at $16^{\circ} \mathrm{C}$ overnight. After phenol extraction and ethanol precipitation, the reaction mixture was dissolved in $2 \mu \mathrm{l}$ water and electroporated into $E$. coli $\mathrm{DH} 10 \beta$. The broad-host-range cosmid vector PLAFR3 was used to construct a gene cosmid library of $\mathrm{R}-b p b 1$. The strategy used for cosmid cloning was as described by Staskavicz et al. (1987). The cosmid bank was introduced into A. eutropbus $\mathrm{CH} 34$ using pRK2013 as a helper plasmid and transconjugants carrying $\mathrm{BphABC}^{+}$recombinant vectors were identified by production of the yellow meta-ring cleavage product, 2-hydroxy-6-oxo-phenylhexa-2,4-dienoate, on Tris/ gluconate plates supplemented with BP. 
Table 2. Transfer frequencies of catabolic pathways from strain JB1 to $A$. eutrophus $\mathrm{CH} 34$ by means of RP4::Mu3A

\begin{tabular}{|lccc|}
\hline Donor (relevant plasmid) & Recipient & $\begin{array}{c}\text { Selected } \\
\text { marker* }\end{array}$ & $\begin{array}{c}\text { Transfer frequency (no. of } \\
\text { transconjugants per } \\
\text { transferred RP4::Mu3A or RP4) }\end{array}$ \\
\hline AE1185 (RP4::Mu3A) & AE53 & Lys $^{+}$ & $10^{-8}$ \\
AE1236 (RP4) & $\mathrm{AE53}$ & $\mathrm{Lys}^{+}$ & $<10^{-9}$ \\
AE1185 (RP4::Mu3A) & $\mathrm{AE53}$ & $\mathrm{Mtol}^{+}$ & $<10^{-9}$ \\
AE1236 (RP4) & $\mathrm{AE53}$ & $\mathrm{Mtol}^{+}$ & $<10^{-9}$ \\
AE1885 (RP4::Mu3A) & $\mathrm{AE53}$ & $\mathrm{Bph}^{+}$ & $10^{-8}$ \\
AE1236 (RP4) & $\mathrm{AE53}$ & $\mathrm{Bph}^{+}$ & $<10^{-9}$ \\
AE1185 (RP4::Mu3A) & $\mathrm{AE53}$ & $\mathrm{Mhb}^{+}$ & $10^{-9}$ \\
AE1236 (RP4) & $\mathrm{AE53}$ & $\mathrm{Mhb}^{+}$ & $<10^{-9}$ \\
AE1185 (RP4::Mu3A) & $\mathrm{AE7}$ & $\mathrm{Tyu}^{+}$ & $10^{-7}$ \\
AE1236 (RP4) & $\mathrm{AE7}$ & $\mathrm{Tyu}^{+}$ & $<10^{-9}$ \\
AE1185 (RP4::Mu3A) & $\mathrm{AE53}$ & $\mathrm{Nah}^{+}$ & $<10^{-9}$ \\
AE1236 (RP4) & $\mathrm{AE53}$ & $\mathrm{Nah}^{+}$ & $<10^{-9}$ \\
\hline
\end{tabular}

* Phenotypes: $\mathrm{Lys}^{+}$, lysine biosynthesis ability; $\mathrm{Mtol}^{+}, \mathrm{Bph}^{+}, \mathrm{Mhb}^{+}, \mathrm{Tyu}^{+}, \mathrm{Nah}^{+}$, abilities to utilize $m$ toluate, biphenyl, $m$-hydroxybenzoate, tyrosine and naphthalene, respectively, as a carbon source.

Chemicals. BP, 3CBA, 4CBA, 2CBA, $m$-toluate, $p$ - toluate, $m$ hydroxybenzoate and naphthalene were obtained from Janssen Chimica. 2CBP, 3CBP and 4CBP were obtained from Ventron. 2,3-Dihydroxybiphenyl was obtained from Sopar.

Growth curves and analysis of free chloride ions. Organisms were grown in $20 \mathrm{ml}$ chloride-free minimal medium containing $\mathrm{BP}$ or CBPs as the sole carbon source, in $125 \mathrm{ml} \mathrm{Wiame} \mathrm{shake}$ flasks at $30^{\circ} \mathrm{C}$, and growth was followed by measuring $\mathrm{OD}_{660}$. Chloride levels were assayed by the colorimetric method of Bergmann \& Sanik (1957). BP and CBPs were added as crystals in amounts corresponding to a concentration of $5 \mathrm{mM}$.

Phenotypic identification of strain JB1. Strain JB1 was identified using API 20NE and BIOLOG identification kits, extensive auxanography (API50CH, API500A and API50AA), and whole-cell fatty acid analysis (Midi, Inc.)

165 rRNA sequencing and analysis. Total genomic DNA of strain JB1 was digested with EcoRI, HindIII, BamHI, PstI, KpnI, $S s t \mathrm{I}$ and $S a l \mathrm{I}$ and after electrophoresis blotted onto Hybond $\mathrm{N}$ (Amersham) membranes. The $16 \mathrm{~S}$ rRNA gene of strain JB1 was localized on a $3 \mathrm{~kb}$ Pst $\mathrm{I}$ fragment by hybridization with a gene probe containing part of the JB1 $16 \mathrm{~S}$ rRNA gene. The gene probe was obtained on total DNA of strain JB1 by PCR with primers 1 and 16 (Wilmotte et al., 1993). PstI $3 \mathrm{~kb}$ fragments of the genomic DNA were cloned by ligation with vector $\mathrm{pSK}^{+}$ (Stratagene) and electroporation into E. coli DH5 $\alpha$. Colony hybridization was performed to identify recombinant clones containing the $16 \mathrm{~S}$ rRNA genes. Afterwards, 16 primers annealing to conserved areas (Wilmotte et al., 1993) and the two M13 primer sites on the vector were used to sequence both strands of the $16 \mathrm{~S}$ rRNA. The Sequenase kit version 2.0 (USB) and the T7 Polymerase kit (Pharmacia) were used following the manufacturers' instructions. The determined sequence was aligned by means of the program DCSE (De Rijk \& De Wachter, 1993) with other known bacterial 16S rRNA sequences according to the primary and secondary structure features (Van de Peer et al., 1994). Dissimilarity values were calculated without taking into account the indels (insertion/deletion events) and were corrected for multiple mutations according to Jukes \& Cantor (1969). All alignment positions were used in the analysis. The database containing the alignment of known bacterial $16 \mathrm{~S}$ rRNA sequences can be consulted on-line and retrieved via WWW and anonymous ftp (Van de Peer et al., 1996). A dendrogram was constructed from the distance matrix by the neighbour-joining method (Saitou \& Nei, 1987), using the software package treecon version 3.0 (Van de Peer \& De Wachter, 1994). The statistical significance of the branches was assessed by bootstrap analysis, involving the construction of 500 re-sampled trees.

\section{RESULTS}

\section{RP4:: Mu3A-mediated mobilization of chromosomally located aromatic catabolic pathways}

$A$. eutrophus $\mathrm{CH} 34$ was unable to use $\mathrm{BP}, m$ - toluate, $m$ hydroxybenzoate or naphthalene as sole carbon sources. Matings were set up to transfer chromosomal DNA segments encoding catabolism of these aromatics, by means of RP4:: Mu3A, from JB1 derivative AE1185 to $A$. eutropbus AE53, a $\mathrm{Lys}^{-}$derivative of $A$. eutrophus $\mathrm{CH} 34$. In order to check the possibility of RP4::Mu3Amediated transfer of chromosomal DNA from AE1185 to $\mathrm{CH} 34$, we looked at complementation of lys-53 in AE53 and tyuB7 in AE7. AE7 is a $\mathrm{CH} 34$ derivative unable to utilize tyrosine as a carbon source. AE1185 was counterselected in all matings by including nickel or zinc in the selective medium.

Transfer of the ability to utilize $\mathrm{BP}\left(\mathrm{Bph}^{+}\right)$and $m$ hydroxybenzoate $\left(\mathrm{Mhb}^{+}\right)$as a carbon source from strain AE1185 to $A$. eutrophus AE53 occurred at frequencies of $10^{-8}$ and $10^{-9}$ per transferred plasmid, respectively (Table 2). No transconjugants able to grow on $m$ - toluate ( $\left.\mathrm{Mtol}^{+}\right)$ or naphthalene $\left(\mathrm{Nah}^{+}\right)$were obtained. Mutations lys-53 
(a)

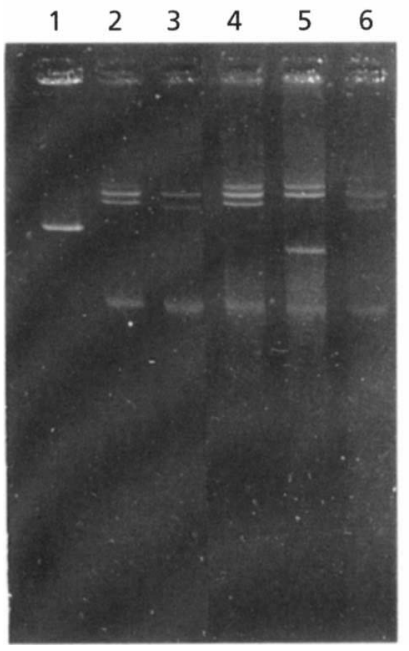

(b)

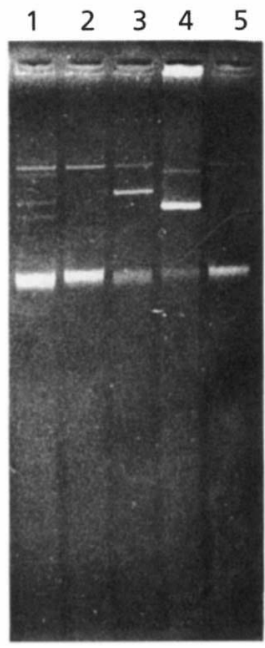

(c)

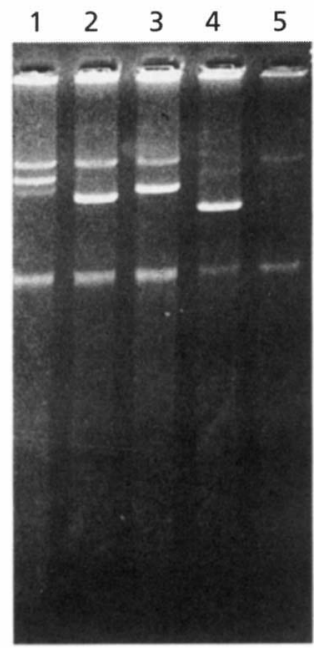

Fig. 1. (a) Plasmid patterns of $\mathrm{Bph}^{+} \mathrm{AE} 53$ transconjugants. Lanes: 1, AE1185 carrying RP4::Mu3A (68 kb); 2-6, Bph $^{+}$AE53 transconjugants. (b) Plasmid patterns of $\mathrm{Mhb}^{+}$AE53 transconjugants. Lanes: 1-3, $\mathrm{Mhb}^{+}$AE53 transconjugants; 4, AE1185 carrying RP4::Mu3A; 5, AE53 carrying pMOL28 (168 kb) and pMOL30 (240 kb). (c) Plasmid patterns of $\mathrm{Tyu}^{+} \mathrm{AE7}$ transconjugants. Lanes: 1-3, $\mathrm{Tyu}^{+}$AE7 transconjugants; 4, AE1185 carrying RP4::MU3A; 5, AE7 carrying pMOL28 $(168 \mathrm{~kb})$ and pMOL30 (240 kb). (a)

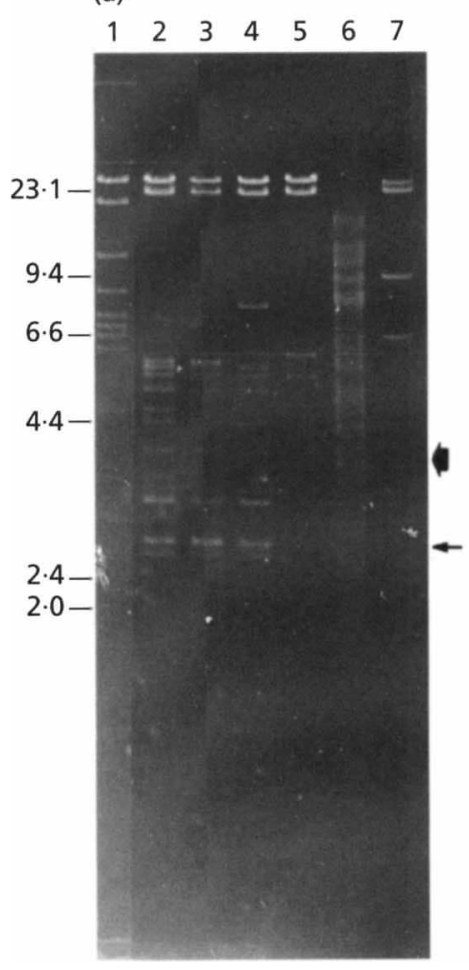

(b)

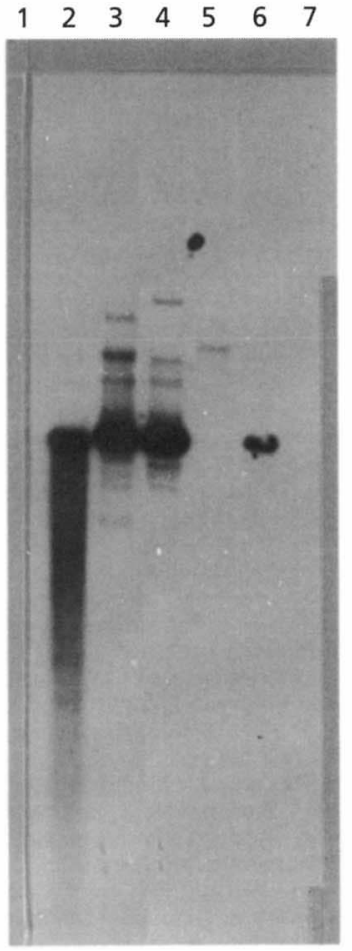

(c)

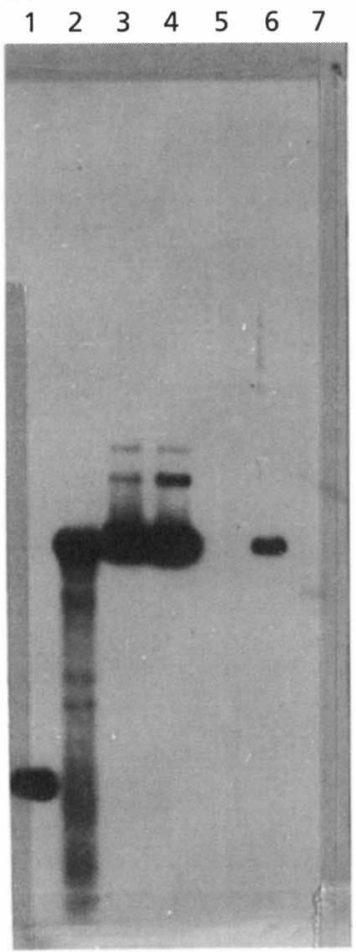

(d)

Fig. 2. (a) Pstl restriction patterns of $B p h^{+}$prime plasmids R-bph1, R-bph2 and R-bph3. (b-d) Southern blot hybridization using the following probes: (b) a $3.8 \mathrm{~kb}$ DNA fragment (see thick arrow in a) common to all Bph ${ }^{+}$prime plasmids; (c) the bphA1 gene of $P$. fluorescens GS15; (d) the bphCD gene cluster of $A$. eutrophus A5. Lanes: 1, RP4::Tn4371; 2, R-bph; 3, R-bph2; 4, R-bph3; 5, RP4:: Mu3A; 6 , total genomic DNA of A. denitrificans JB1; 7, Hindlll-digested $\lambda$. The thin arrow in (a) indicates the Pstl-Pstl fragment of Mu3A duplicated in the prime plasmids.

and $t y u B 7$ were both complemented at a frequency of $10^{-8}$, the latter complementation being a third case of transfer of catabolic genes between strain JB1 and $A$. eutrophus $\mathrm{CH} 34$. No transconjugants were obtained in the absence of the RP4::Mu3A plasmid or using RP4 as a mobilizing plasmid, which suggested the involvement of Mu3A in the mobilization of chromosomal DNA. Nineteen $\mathrm{Bph}^{+}$ lys-53 transconjugants were retained and were designated 
Distance 0.1

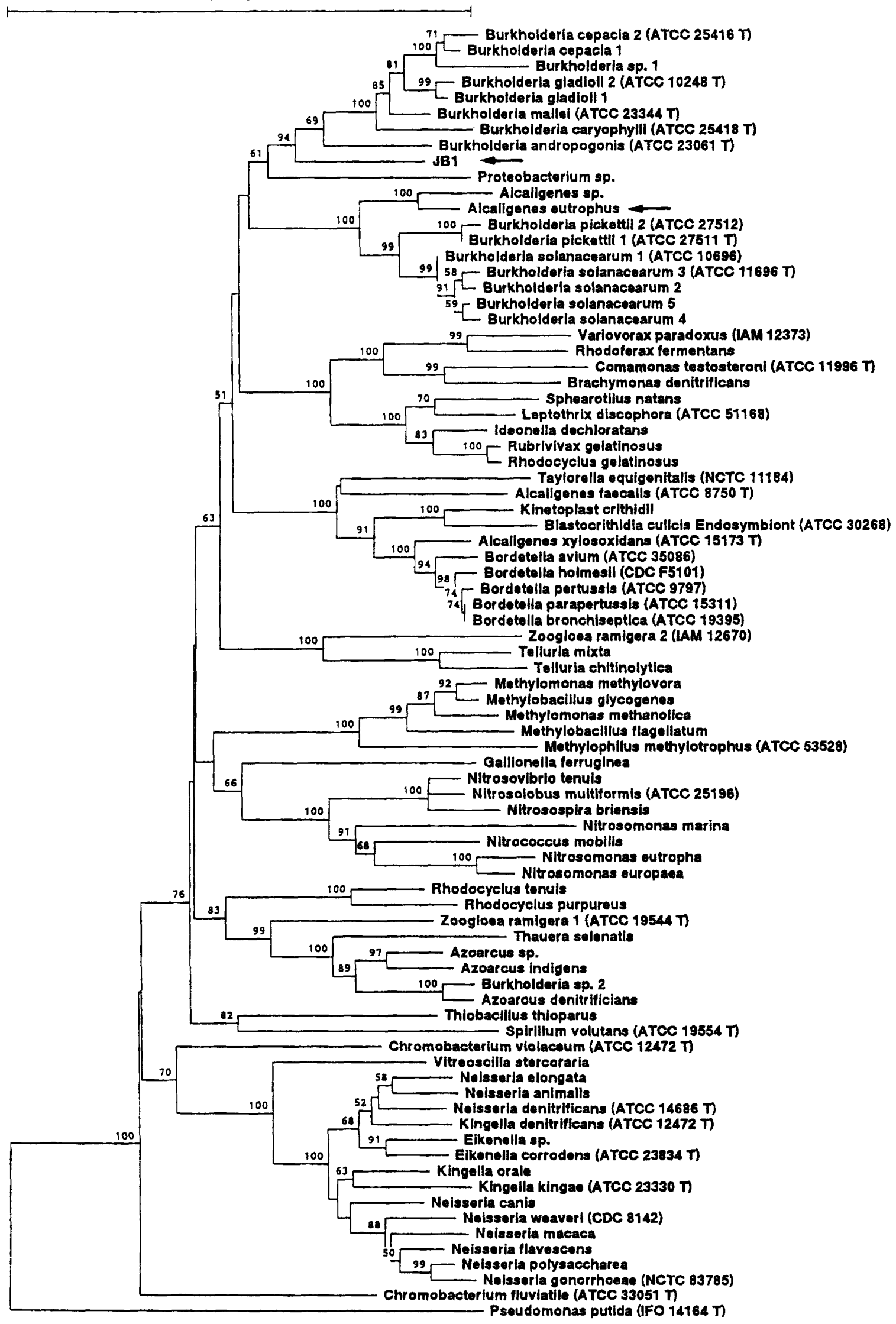

Fig. 3. For legend see facing page. 
AE1216 to AE1235. The three $\mathrm{Mhb}^{+}$lys-53 transconjugants were designated AE1236, AE1237 and AE1238.

\section{Identification and stability of $\mathrm{Bph}^{+}$prime plasmids}

Plasmid extraction from the $\mathrm{Bph}^{+}$transconjugants demonstrated the presence of various rearranged RP4::Mu3A plasmids. Examples of RP4::Mu3A plasmids with insert are shown in Fig.1(a), lanes 2, 3, 4 and 6. Other transconjugants had no insert or demonstrated deletions (lane 5). From the three $\mathrm{Bph}^{+}$transconjugants carrying enlarged RP4::Mu3A plasmids shown in lanes 2, 3 and 4, the plasmids were transferred to $E$. coli, selecting for the antibiotic resistance markers, and then back to $A$. eutropbus with $100 \%$ co-transfer of the catabolic phenotype. This demonstrated the presence of plasmid primes containing the $b p b$ catabolic marker. The plasmid primes were designated R-bpb1, R-bpb2 and R$b p b 3$. Analysis of $\mathrm{Bph}^{+}$AE53 transconjugants carrying RP4::Mu3A without inserts or with deletions demonstrated that in some cases the Tra functions were lost from the plasmids, as they were not able to transfer either the antibiotic resistance or the catabolic markers. From other transconjugant strains, transfer of RP4:: Mu3A resistance markers occurred at a frequency of $10^{-2}$ per recipient, whereas transfer of $\mathrm{Bph}^{+}$occurred at a frequency of $10^{-7}$, suggesting that the $\mathrm{Bph}^{+}$determinant had integrated in the chromosome and could be further mobilized by means of RP4::Mu3A.

Similar observations were found with the $\mathrm{Mhb}^{+} \mathrm{AE53}$ transconjugants (Fig. 1b). Only from the transconjugant carrying an enlarged plasmid (Fig. 1b, lane 2) could the plasmid be transferred to $E$. coli, selecting for the antibiotic resistance marker, and back to $A$. eutrophus with $100 \%$ co-transfer of the catabolic marker. The prime plasmid was designated R-mbb1.

The $\mathrm{Tyu}^{+}$transconjugants all contained enlarged RP4:: Mu3A plasmids. Examples are shown in Fig. 1(c). For all plasmids, the resistance markers and catabolic markers were $100 \%$ co-transferred.

\section{Phenotypic analysis of $A$. eutrophus strains carrying $\mathrm{Bph}^{+}$and Mhb+ RP4::Mu3A prime plasmids}

A. eutrophus AE53 $\mathrm{Bph}^{+}$and $\mathrm{Mhb}^{+}$transconjugants were tested for growth on other aromatic compounds that the parental strain $A$. eutrophus $\mathrm{CH} 34$ is unable to utilize as a sole carbon source. $\mathrm{Bph}^{+}$transconjugant strains were able to grow on 2-, 3-, and 4-CBP, and on diphenylmethane. No growth was observed with naphthalene, $m$-toluate, $m$ hydroxybenzoate or gentisate. All $\mathrm{Mhb}^{+}$transconjugant strains also grew on gentisate but not on naphthalene, $m$-toluate, $\mathrm{BP}$, diphenylmethane or $\mathrm{CBPs}$.

\section{Genetic analysis of $\mathrm{Bph}^{+}$prime plasmids}

$\mathbf{R}-b p b 1, \mathbf{R}-b p b 2$ and $\mathbf{R}-b p b 3$ were isolated from E. coli and digested with $P_{s t} \mathrm{I}$ (Fig. 2a). This enzyme cuts twice in the Mu3A element of RP4::Mu3A. As such, the presence of a duplicated copy of the Mu3A element in the prime plasmids can easily be visualized after Pst I digestion and gel electrophoresis (Van Gijsegem et al., 1987). The $2 \mathrm{~kb}$ Pst I-Pst $\mathrm{I}$ Mu3A internal fragment clearly showed a brightened band on the gel, demonstrating duplication of the element (Fig. 2a). The R-bph plasmids gave several common fragments, showing that in the three cases the same region of the JB1 chromosome had been mobilized with different flanking DNA sequences. The total lengths of the DNA inserts in R-bpb1, R-bph2 and R-bpb3 were estimated as 50,52 , and $47 \mathrm{~kb}$, respectively. The JB1 chromosomal origin of the in vivo cloned DNA was demonstrated using a $3.8 \mathrm{~kb}$ DNA fragment, common to all prime plasmids, as a probe (see Fig. $2 \mathrm{~b}$ ). The $b p h A 1$ and $b p h C D$ probes revealed on all $\mathrm{Bph}^{+}$prime plasmids a 2.6 and a $4.4 \mathrm{~kb}$ fragment, respectively (Fig. 2c, d). The $4.4 \mathrm{~kb}$ fragment was cloned in the unique PstI site of pRK415 and electroporated into E. coli DH10B. $\mathrm{Tc}^{\mathrm{r}}$ colonies carrying the expected insert turned yellow after spraying with $0 \cdot 1 \% 2,3$-dihydroxybiphenyl/diethyl ether solution, demonstrating expression of the meta-cleavage enzyme, the $b p b C$ gene product. The cloned fragment complemented $b p b D 1$ mutant $A$. eutropbus AE992, showing that both $b p b C$ and $b p b D$ were present. Partial Sau3A1digested R- $b p h 1$ was cloned into cosmid pLAFR 3 and introduced into $A$. eutropbus CH34. Several clones carrying inserts of around $20 \mathrm{~kb}$, able to convert BP into the yellow meta-cleavage product were obtained, showing the presence of $b p h A B C$ genes on the prime plasmid.

\section{Transfer of R-bph1 into various soil bacteria: construction of a 3-chlorobiphenyl-mineralizing hybrid strain}

Prime plasmid R- $b p b 1$ was transferred from E. coli CM1073 to various $\alpha$-, $\beta$ - and $\gamma$-Proteobacteria. Expression of $\mathrm{Bph}^{+}$was observed in the $\gamma$-Proteobacteria Pseudomonas aeruginosa $7 \mathrm{NSK} 2$ and $P$. aeruginosa JB2, in the $\beta$-Proteobacteria Comamonas testosteroni ATCC 11996, Burkbolderia cepacia ATCC 17616, B. cepacia JH230, A. eutrophus ATCC 17697, $A$. eutrophus H16, $A$. eutrophus JMP222 and $A$. denitrificans ATCC 15749, and in Pseudomonas sp. B13 (subgroup unknown). Expression was not observed in the $\gamma$-Proteobacteria E. coli, Pseudomonas fluorescens V50, Acinetobacter calcoaceticus ATCC 10153, Xantbomonas maltophilia ATCC 13637, Pseudomonas putida $\mathrm{PaW} 1$ and $P$. putida ATCC 12633 , in the $\beta$-Proteobacterium Aquaspirillum autotropbicum ATCC 29984, or in the $\alpha$-Proteobacterium Rhizobium meliloti B23.

Fig. 3. Positions of donor strain JB1 and recipient strain $\mathrm{CH} 34$ (both arrowed) in the distance tree of $\beta$-Proteobacteria based on 165 rRNA sequence analysis. The $\gamma$-Proteobacterium Pseudomonas putida IFO14169T was used as outgroup. Bootstrap values are indicated at the corresponding nodes and expressed in \%. The distance between two species is obtained by summing the lengths of the connecting horizontal branches using the scale at the top. T denotes a type strain. 
Strains $P$. aeruginosa JB2, B. cepacia JH230 and Pseudomonas sp. B13 are able to utilize chlorinated benzoates, the endproducts of CBP metabolism, as carbon sources. The corresponding Pseudomonas sp. $\mathrm{B} 13 \mathrm{Bph}^{+}$transconjugants were able to grow on $5 \mathrm{mM} 3 \mathrm{CBP}$ with stoichiometric release of chloride ions, demonstrating mineralization of 3CBP (data not shown). B. cepacia JH230 and P. aeruginosa $\mathrm{JB} 2 \mathrm{Bph}^{+}$transconjugants on the other hand were able to utilize BP, 3CBP, 4CBP and 2CBP, as well as various mono- and di-chlorinated benzoates, but no release of chloride ions could be detected with the CBPs. A black product accumulated during the growth on 2CBP and $3 \mathrm{CBP}$ indicating accumulation of chlorinated catechols or phenylcatechols.

\section{Evolutionary relationship between donor and recipient bacterium}

To determine the degree of evolutionary relationship between donor and recipient bacterium, we performed identification tests of strain JB1 and sequenced its $16 \mathrm{~S}$ rRNA. The recipient strain CH34 has been shown by $16 \mathrm{~S}$ rRNA sequence analysis to belong to the $A$. eutropbus cluster ( $\mathrm{H}$. Brim and others, unpublished results). Phenotypic identification methods allocated strain JB1 to the $\beta$-Proteobacteria, with tentative identifications as Alcaligenes xylosoxidans subsp. denitrificans (API20NE) and Bordetella parapertussis (BIOLOG). The auxanography pattern on the other hand did not conform to these descriptions. The fatty acid profile gave Burkbolderia cepacia as a possible identification, although with a low score. Analysis of the $16 \mathrm{~S}$ rRNA sequence demonstrated that strain JB1 is closer to B. cepacia than to the Alcaligenes lineage. The $16 \mathrm{~S}$ rRNA gene of strain JB1 has a length of $1588 \mathrm{bp}$. Fig. 3 shows the distance tree constructed from all available $16 \mathrm{~S}$ rRNA sequences of bacteria belonging to the $\beta$-Proteobacteria and includes strain JB1. It shows that strain JB1 belongs to a lineage containing B. cepacia, Burkbolderia gladioli, Burkbolderia mallei and Burkbolderia andropogonis. B. andropogonis is the most closely related strain with $93.8 \% 16 \mathrm{~S}$ rRNA similarity with JB1. The $16 \mathrm{~S}$ rRNA sequence of $A$. eutrophus shows $92.4 \%$ similarity with the 16S rRNA sequence of strain JB1. It can be concluded that the RP4::Mu3A-mediated in vivo transfer of the $b p h, m b b$ and tyu catabolic genes occurred between two different branches of the $\beta$-Proteobacteria.

\section{DISCUSSION}

This paper describes the in vivo cloning of chromosomally borne aromatic catabolic genes enabling the recipient organism to utilize a new carbon source by receiving a new set of catabolic genes. It shows that chromosomally located PCB catabolic pathways as suggested by other authors can be mobilized between bacteria and that broadhost-range plasmids and transposons may mediate transfer. In contrast with the PCB catabolic genes of $A$. eutropbus A5, in which the mobilization was achieved by transposition of the catabolic genes contained within a transposon located in the chromosome (Springael et al., 1993b), here, the catabolic genes were recruited due to the interaction with a transposable element present on the plasmid. Transfer and expression was achieved between bacteria belonging to two different branches of the $\beta$ Proteobacteria, as shown by the distance tree based on $16 \mathrm{~S}$ rRNA sequence analysis.

The transferred JB1 $\mathrm{Bph}^{+}$chromosomal fragment also conferred the ability to catabolize CBPs and diphenylmethane upon $A$. eutrophus $\mathrm{CH} 34$. In most cases, $\mathrm{BP}$ and CBPs are catabolized by the same set of enzymes (Ahmad et al., 1990; Hayase et al., 1990; Mondello, 1989). The hybridization experiments using $b p b A 1$ and $b p b C$ as probes and the cloning of the $b p h A B C D$ genes from the $\mathrm{Bph}^{+}$prime plasmids indicate that only one set of genes was present in strain JB1. The presence of several different $b p b C$ genes was demonstrated in P. putida OU83 (Khan \& Walia, 1989), in Rbodococcus erytbropolis TA421 (Maeda et al., 1995) and in Rhodococcus globerulus P6 (Asturias \& Timmis, 1993). Furthermore, PCB-degrading bacteria differ in their ability to utilize diphenylmethane as a carbon source (Furukawa et al., 1989). If the same set of genes is involved in metabolization of both diphenylmethane and the BP compounds, it shows once more the catabolic versatility of the BP catabolic enzymes and the interesting differences in the substrate selectivity patterns between BP catabolic pathways from different PCB degraders (Mondello, 1989; Erickson \& Mondello, 1993). The $\mathrm{Mhb}^{+}$prime plasmids also conferred degradation of gentisate upon $A$. eutrophus $\mathrm{CH} 34$, suggesting that $m$ hydroxybenzoate is degraded via gentisate in strain JB1. A similar pathway is used by $P$. putida and by Pseudomonas alcaligenes (Hopper \& Taylor, 1975; Poh \& Bayly, 1980).

The in vivo cloned BP degradation pathway of strain JB1 did not confer the ability to grow on BP upon all bacterial strains into which the pathway was introduced. This could be due to the lack of suitable regulatory elements or other factors required to express the pathway genes in these hosts. Generally, the BP degradation pathway of strain JB1 seems to be well-expressed in bacteria of the $\beta$ group of the Proteobacteria. Only $A$. autotrophicum transconjugants did not grow on BP. From the $\gamma$-group, only $P$. aeruginosa expressed the pathway. On the other hand, its expression range seems to be larger than that of the BP degradation pathway present on Tn4371, which seemed to be well expressed only in $A$. eutrophus and not in other $\beta$-Proteobacteria such as B. cepacia and Chromobacterium (Springael et al., 1993b). Transfer of the $\mathrm{Bph}^{+}$ pathway into chlorobenzoate-degrading bacteria did lead to transconjugants able to completely mineralize $\mathrm{CBP}$ in Pseudomonas sp. B13, but not in $P$. aeruginosa $\mathrm{JB} 2$ and $B$. cepacia JH230. The activity of a meta-cleavage pathway and a chlorocatechol ortbo-cleavage pathway in the same organism at the same time may result in toxic effects or repression of certain enzymes (Adams et al., 1992; Sondossi et al., 1992). Pathway assembly needs a synchronized and a regulated expression of both peripheral and lower pathway together in one organism.

Prime plasmid formation may be a mechanism by which catabolic genes can be acquired by plasmids. Although the frequency of gene transfer mediated by this mechanism might be expected to be relatively low in nature, the 
process may play a role when conditions are favourable and selection pressure is high. The presence of mobilizing plasmids with broad-host-range transfer functions in natural populations has been described (McPherson \& Gealt, 1986; Top et al., 1994). Natural IncP $\alpha$ plasmids such as R68.45 and R18.18 isolated from clinical isolates are able to mobilize chromosomal DNA and to form prime plasmids in different bacterial genera (Haas \& Holloway, 1976; Haas \& Reimann, 1989). Little is known about the capability of catabolic and other environmental plasmids to transfer, mobilize or recruit genes. Some catabolic plasmids belong to the Inc $\beta \beta$ group (Burlage $e t$ al., 1990), but their $\mathrm{Cma}^{+}$and prime plasmid formation potential has yet to be demonstrated. The IncP-9 TOL plasmid is able to directly mobilize and retromobilize between $P$. putida strains chromosomal markers such as the camphor catabolic operon and a kanamycin resistance gene marker integrated at various locations in the chromosome. The mobilized DNA seems to re-insert into the chromosome of the recipient rather than remaining in the plasmid after conjugation (Maë et al., 1991; RamosGonzalez et al., 1994). Prime plasmid formation would leave the catabolic pathway genes flanked by repeat elements, as is often found with catabolic plasmids (Eaton \& Timmis, 1986; Layton et al., 1992; Meulien et al., 1981; Nakatsu et al., 1991; van der Meer et al., 1991). Many of these repeats have been shown to be IS elements, linked together with the catabolic genes to form composite transposons (Nakatsu et al., 1991; van der Meer et al., 1991). In A. eutrophus strain NH9, the 3CBA catabolic gene cluster present on an IncP $\alpha$ transmissible plasmid, is flanked by IS21-like sequences (Ogawa \& Miyashita, 1995). On R68.45, IS 21 is responsible for prime plasmid formation. Wyndham et al. (1994) suggested that the $3 \mathrm{CBA}$ catabolic plasmid IncP $\beta$ pBRC 60 evolved by prime plasmid formation leaving the catabolic genes flanked by IS1071.

In vivo cloning can be used for the construction of strains for xenobiotic degradation. It can be used for in vivo cloning of catabolic pathways from bacteria in which the mobilizing plasmid is able to replicate and whose expression may be expected in the recipient strain. The catabolic prime plasmids can easily be introduced into a variety of relevant bacteria to investigate the expression of the cloned catabolic genes (Haugland et al., 1990; Kolenc et al., 1988). Here, in vivo cloning led to new PCBdegrading heavy-metal-resistant bacteria with potential applications in the decontamination of mixed organic/ inorganic pollutions (Springael et al., 1993a, 1994) and to a hybrid chlorobiphenyl/chlorobenzoate-mineralizing pathway in strain Pseudomonas sp. B13. Moreover, the presence of the catabolic genes on broad-host-range plasmids may be of interest for the expansion of the catabolic versatility of indigenous populations of a polluted site (Barkay et al., 1993; Fulthorpe \& Wyndham, 1989, 1992; McClure et al., 1989).

\section{ACKNOWLEDGEMENTS}

We thank L. Diels, K. De Wilde, M. Faelen, A. Toussaint, D. van der Lelie and A. Wilmotte for useful discussions and suggestions, D. Janssens and K. Kersters for phenotypic identification of strain JB1, and S. Nicolai for construction of the phylogenetic tree. This work was partially supported by a grant from the Flemish Government (VLAB-ETC-003) and by the EC programme Environment (EVSV-CT92-0192).

\section{REFERENCES}

Adams, R. H., Huang, C. M., Higson, F. K., Brenner, V. \& Focht, D. D. (1992). Construction of a 3-chlorobiphenyl-utilizing recombinant from an intergeneric mating. Appl Environ Microbiol 58, 647-654.

Ahmad, D., Massé, R. \& Sylvestre, M. (1990). Cloning and expression of genes involved in 4-chlorobiphenyl transformation by Pseudomonas testosteroni: homology to polychlorobiphenyl-degrading genes in other bacteria. Gene 86, 53-61.

Assinder, S. J. \& Williams, P. A. (1990). The TOL plasmids; determinants of the catabolism of toluene and the xylenes. $A d v$ Microb Pbysiol 31, 2-69.

Asturias, J. A. \& Timmis, K. N. (1993). Three different 2,3dihydroxybiphenyl-1,2-dioxygenase genes in the Gram-positive polychlorobiphenyl-degrading bacterium Rbodococcus globerulus P6. $J$ Bacteriol 175, 4631-4640.

Barkay, T., Liebert, C. \& Giliman, M. (1993). Conjugal gene transfer to aquatic bacteria detected by the generation of a new phenotype. Appl Environ Microbiol 59, 807-814.

Bergmann, J. G. \& Sanik, J. (1957). Determination of trace amounts of chlorine in naphtha. Anal Chem 29, 241-243.

Bron, S. \& Venema, G. (1972). Ultraviolet inactivation and excisionrepair in Bacillus subtilis. Construction of a transformable eight-fold auxotrophic strain and two ultra-violet sensitive derivatives. Mutat Res 15, 1-10.

Burlage, R. S., Bemis, L. A., Layton A. C., Sayler, G. S. \& Larimer, F. (1990). Comparative genetic organization of incompatibility group P degradative plasmids. $J$ Bacteriol 172, 6818-6825.

Carrington, B., Lowe, A., Shaw, L. E. \& Williams, P. A. (1994). The lower pathway operon for benzoate catabolism in biphenyl-utilizing Pseudomonas sp. strain IC and the nucleotide sequence of the $b p b E$ gene for catechol 2,3-dioxygenase. Microbiology 140, 499--508.

De Rijk, P. \& De Wachter, R. (1993). DCSE, an interactive tool for sequence alignment and secondary structure research. Comput Applic Biosci 9, 735-740.

De Wilde, K., Springael, D. \& Mergeay, M. (1992). Cloning of the $b p h C$ gene of the PCB catabolic transposon Tn4371 from Alcaligenes eutrophus A5. Arch Int Physiol Biocbim 101, B33.

Don, R. H. \& Pemberton, J. M. (1981). Properties of six pesticide degradation plasmids isolated from Alcaligenes eutrophus and Alcaligenes paradoxus. J Bacteriol 145, 681-686.

Dorn, E., Hellwig, M., Reineke, W. \& Knackmuss, H. J. (1974). Isolation and characterization of a 3-chlorobenzoate degrading pseudomonad. Arch Microbiol 99, 61-70.

Eaton, R. W. \& Timmis, K. N. (1986). Spontaneous deletion of a 20 kilobase DNA segment carrying genes specifying isopropylbenzene metabolism in Pseudomonas putida RE204. J Bacteriol 168, 428-430.

Erickson, D. E. \& Mondello, F. J. (1993). Enhanced biodegradation of polychlorinated biphenyls after site-directed mutagenesis of a biphenyl dioxygenase gene. Appl Environ Microbiol 59, 3858-3862.

Fulthorpe, R. R. \& Wyndham, R. C. (1989). Survival and activity of a 3-chlorobenzoate-catabolic genotype in a natural system. Appl Environ Microbiol 55, 1584-1590. 
Fulthorpe, R. R. \& Wyndham, R. C. (1992). Involvement of a chlorobenzoate-catabolic transposon, $\mathrm{Tn} 5271$, in community adaptation to chlorobiphenyl, chloroaniline, and 2,4-dichlorophenoxyacetic acid in a freshwater ecosystem. Appl Environ Microbiol 58, 314-325.

Furukawa, K. \& Miyazaki, T. (1986). Cloning of a gene cluster encoding biphenyl and chlorobiphenyl degradation in Pseudomonas pseudoalcaligenes. J Bacteriol 166, 392-398.

Furukawa, K., Hayase, N., Taira, K. \& Tomizuka, N. (1989). Molecular relationship of chromosomal genes encoding biphenyl/ polychlorinated biphenyl catabolism: some soil bacteria possess a highly conserved $b p h$ operon. J Bacteriol 171, 5467-5472.

Haas, D. \& Holloway, B. C. (1976). R factor variants with enhanced sex factor activity in Pseudomonas aeruginosa. Mol Gen Genet 144, 243-251.

Haas, D. \& Reimann, C. (1989). Use of IncP plasmids in chromosomal genetics of Gram-negative bacteria. In Promiscuous Plasmids of Gram-negative Bacteria, pp. 185-206. Edited by C. M. Thomas. London: Academic Press.

Haugland, R. A., Schlamm, D. J., Lyons, R. P., Sferra, P. R. \& Chakrabarty, A. M. (1990). Degradation of chlorinated phenoxyacetate herbicides 2,4-dichlorophenoxyacetic acid and 2,4,5-trichlorophenoxyacetic acid by pure and mixed bacterial cultures. Appl Environ Microbiol 5, 1357-1362.

Havel, J. \& Reineke, W. (1991). Total degradation of various chlorobiphenyls by cocultures and in vivo constructed pseudomonads. FEMS Microbiol Lett 78,163-170.

Hayase, N., Taira, K. \& Furukawa, K. (1990). Pseudomonas putida KF715 bph $A B C D$ operon encoding biphenyl and polychlorinated biphenyl degradation: cloning, analysis, and expression in soil bacteria. J Bacteriol 172, 1160-1164.

Herrmann, H., Janke, D., Krejsa, S. \& Roy, M. (1988). In vivo generation of R68.45-pPGH1 hybrid plasmid conferring a $\mathrm{Phl}^{+}$ (meta pathway) phenotype. Mol Gen Genet 214, 173-176.

Hickey, W. J. \& Focht, D. D. (1990). Degradation of mono, di- and trihalogenated benzoic acids by Pseudomonas aeruginosa JB2. Appl Environ Microbiol 56, 3842-3850.

Hickey, W. J., Searles, D. B. \& Focht, D. D. (1992). Mineralization of 2-chloro- and 2,5-dichlorobiphenyl by Psendomonas sp. strain UCR2. FEMS Microbiol Lett 98, 175-180.

Höfte, M., Mergeay, M. \& Verstraete, W. (1990). Marking the Rhiropseudomonas strain 7NSK2 with a Mud(lac) element for ecological studies. Appl Environ Microbiol 56, 1046-1052.

Hopper, D. J. \& Taylor, D. G. (1975). Pathways for the degradation of $m$-cresol and $p$-cresol by Pseudomonas putida. J Bacteriol 122, 1-6.

Ish-Horowicz, D. I. \& Burke, J. F. (1981). Rapid and efficient cosmid cloning. Nucleic Acids Res 9, 2989-2998.

Jukes, T. H. \& Cantor, C. R. (1969). Evolution of protein molecules. In Mammalian Protein Metabolism, pp. 21-132. Edited by H. N. Munro. New York: Academic Press.

Kado, C. I. \& Liu, S. T. (1981). Rapid procedure for detection and isolation of large and small plasmids. J Bacteriol 145, 1365-1373.

Keen, N. T., Tamaki, S., Kobayashi, D. \& Trollinger, D. (1988). Improved broad-host-range plasmids for DNA cloning in Gramnegative bacteria. Gene 70, 191-197.

Khan, A. \& Walia, S. (1989). Cloning of bacterial genes specifying degradation of 4-chlorobiphenyl from Pseudomonas putida OU83. Appl Environ Microbiol 55, 798-805.

Kimbara, K., Hashimoto, T., Fukuda, M., Koana, T., Takagi, M., Oishi, M. \& Yano, K. (1989). Cloning and sequencing of two tandem genes involved in degradation of 2,3-dihydroxybiphenyl to benzoic acid in the polychlorinated biphenyl-degrading soil bacterium Pseudomonas sp. strain KKS102.J Bacteriol 171, 2740-2747.

Kolenc, R. J., Innis, W. E., Glick, B. R., Robinson, C. W. \& Mayfield, C. I. (1988). Transfer and expression of mesophilic plasmidmediated degradative capacity in a psychrotrophic bacterium. Appl Environ Microbiol 54, 638-641.

Layton, A. C., Sanseverino, J., Wallace, W., Corcoran, C., \& Sayler, G. S. (1992). Evidence for 4-chlorobenzoic acid dehalogenation mediated by plasmids related to pSS50. Appl Environ Microbiol 58, 399-402.

Lejeune, P., Mergeay, M., van Gijsegem, F., Faelen, M., Gerits, G. \& Toussaint, A. (1983). Chromosome transfer and R-prime plasmid formation mediated by plasmid pULB113 (RP4::Mini-Mu) in Alcaligenes eutrophus $\mathrm{CH} 34$ and Pseudomonas fiuorescens 6.2.J Bacteriol 155, 1015-1026.

Lloyd-Jones, G., de Jong, C., Ogden, R. C., Duetz, W. A. \& Williams, P. A. (1994). Recombination of the $b p b$ (biphenyl) catabolic genes from plasmid $\mathrm{pWW} 100$ and their deletion during growth on benzoate. Appl Environ Microbiol 60, 691-696.

McClure, N. C., Weightman, A. J. \& Fry, J. C. (1989). Survival of Pseudomonas putida UWC1 containing cloned catabolic genes in a model activated sludge unit. Appl Environ Microbiol 55, 2627-2634.

McPherson, P.\& Gealt, M. A. (1986). Isolation of indigenous waste water bacterial strains capable of mobilizing plasmid pBR325. Appl Environ Microbiol 51, 904-909.

Mäe, A. A., Habicht, Y. K., Nurk, A. E. \& Heinaru, A. L. (1991). Transposons Tn4652 and Tn 3614 of the TOL plasmid pWWO are involved in conjugal mobilization of chromosomally located catabolic cam-operons. Genetika 27, 773-782.

Maeda, M., Chung, S. Y., Song, E. \& Kudo, T. (1995). Multiple genes encoding 2,3-dihydroxybiphenyl 1,2-dioxygenase in the Gram-positive polychlorinated biphenyl-degrading bacterium Rbodococcus erytbropolis TA421, isolated from a termite ecosystem. Appl Environ Microbiol 61, 549-555.

van der Meer, J. R., Zehnder, A. J. B. \& de Vos, W. M. (1991). Identification of a novel composite transposable element, Tn5280, carrying chlorobenzene dioxygenase genes in Pseudomonas sp. strain P51. J Bacteriol 173, 7077-7083.

Mergeay, M., Nies, D., Schlegel, H. G., Gerits, J., Charles, P. \& van Gijsegem, F. (1985). Alcaligenes eutropbus $\mathrm{CH} 34$ is a facultative chemolithotroph with plasmid-bound resistance to heavy metals. $J$ Bacteriol 162, 328-334.

Meulien, P., Downing, R. G. \& Broda, P. (1981). Excision of the $40 \mathrm{~kb}$ segment of the TOL plasmid from Pseudomonas putida mt-2 involves direct repeats. Mol Gen Genet 184, 97-101.

Mokross, H., Schmidt, E. \& Reineke, W. (1990). Degradation of 3chlorobiphenyl by in vivo constructed hybrid Pseudomonads. FEMS Microbiol Lett 71, 179-186.

Mondello, F. J. (1989). Cloning and expression in Escherichia coli of $P_{\text {seudomonas }} \mathrm{sp}$. strain LB400 genes encoding polychlorinated biphenyl degradation. J Bacteriol 171, 1725-1732.

Nakatsu, C., Ng, J., Singh, R., Straus, N. \& Wyndham, R. C. (1991). Chlorobenzoate catabolic transposon $\operatorname{Tn} 5271$ is a composite class I element with flanking class II insertion sequences. Proc Natl Acad Sci USA 88, 8312-8316.

Ogawa, N. \& Miyashita, K. (1995). Recombination of a 3 chlorobenzoate catabolic plasmid from Alcaligenes eutropbus NH9 mediated by direct repeats. Appl Environ Microbiol 61, 3788-3795.

Parsons, J. R. \& Storms, M. C. M. (1989). Biodegradation of chlorinated dibenzo- $p$-dioxins in batch and continous cultures of strain JB1. Chemosphere 19, 1297-1308. 
Parsons, J. R., Sijm, D. T. H. M., van Laar, A. \& Hutzinger, O. (1988). Biodegradation of chlorinated biphenyls and benzoic acids by a Pseudomonas strain. Appl Microbiol Biotechnol 29, 81-84.

Parsons, J. R., Ratsak, C. \& Siekerman, C. (1990). Biodegradation of chlorinated dibenzofurans by an Alcaligenes strain. In Organobalogen Compounds (Proceedings of Dioxin'90-EPRI Seminar, Bayreuth, September 10-14, 1990), vol. 10, pp. 377-380. Edited by O. Hutzinger \& H. Fiedler. Bayreuth: Ecoinforma Press.

Peloquin, L. \& Greer, C. W. (1993). Cloning and expression of the polychlorinated biphenyl-degradation gene cluster from Arthrobacter M5 and comparison to analogous genes from Gram-negative bacteria. Gene 125, 35-40.

Poh, C. L. \& Bayly, R. C. (1980). Evidence for isofunctional enzymes used in $m$-cresol and 2,5-xylenol degradation via the gentisate pathway in Pseudomonas alcaligenes. J Bacteriol 143, 59-69.

Ramos-Gonzalez, M. I., Ramos-Diaz, M. A. \& Ramos, J. L. (1994). Chromosomal gene capture mediated by the Pseudomonas putida TOL catabolic plasmid. $J$ Bacteriol 176, 4635-4641.

Sadouk, A. \& Mergeay, M. (1993). Chromosome mapping in Alcaligenes eutropbus CH34. Mol Gen Genet 240, 181-187.

Saitou, N. \& Nei, M. (1987). The neighbor-joining method: a new method for reconstructing phylogenetic trees. Mol Biol Evol 4, 406-425.

Selifonov, S. A. \& Starovoitov, I. I. (1991). Comparative study of the enzymes of meta-cleavage of the aromatic ring in strains of the bacterium Pseudomonas with plasmid and chromosomal genetic control of biphenyl and $m$-toluate catabolism. Biochemistry 55, 1616-1623.

Sondossi, M., Sylvestre, M. \& Ahmad, D. (1992). Effects of chlorobenzoate transformation on the Pseudomonas testosteroni biphenyl and chlorobiphenyl degradation pathway. Appl Environ Microbiol 58, 485-495.

Springael, D., Diels, L., Hooyberghs, L., Kreps, S. \& Mergeay, M. (1993a). Construction and characterization of heavy metal resistant haloaromatic degrading Alcaligenes eutrophus strains. Appl Environ Microbiol 59, 334-339.

Springael, D., Kreps, S. \& Mergeay, M. (1993b). Identification of a catabolic transposon, Tn4371, carrying biphenyl and 4-chlorobiphenyl degradation genes in Alcaligenes eutrophus A5. J Bacteriol 175, 1674-1681.

Springael, D., Diels, L. \& Mergeay, M. (1994). Transfer and expression of PCB-degradative genes into heavy metal resistant Alcaligenes eutrophus strains. Biodegradation 5, 343-357.

Staskawicz, B., Dahlbeck, D., Keen, N., \& Napoli, C. (1987). Molecular characterization of cloned avirulence gene from race 0 and race 1 of Pseudomonas syringae pv. glycinea. J Bacteriol 169, 5789-5794.

Steinblichel, A., Kuhn, M., Niedrig, M. \& Schlegel, H. G. (1983). Fermentation enzymes in strictly aerobic bacteria: comparative studies on strains of the genus Alcaligenes and on Nocardia opaca and Xanthobacter autotrophicus. J Gen Microbiol 129, 2825-2835.

Taira, K., Hirose, J., Hayashida, S. \& Furukawa, K. (1992). Analysis of $b p h$ operon from the polychlorinated biphenyl-degrading strain of Pseudomonas pseudoalcaligenes KF707. J Biol Chem 267, 4844-4853.

Top, E., de Smet, I., Verstraete, W., Dijkmans, R. \& Mergeay, M. (1994). Exogenous isolation of mobilizing plasmids from polluted soils and sludges. Appl Environ Microbiol 60, 831-839.

Van Gijsegem, F. \& Toussaint, A. (1982). Chromosome transfer and $\mathrm{R}$-prime formation by an RP4::mini Mu derivative in Escherchia coli, Salmonella typhimurium, Klebsiella pneumoniae and Proteus mirabilis. Plasmid 7, 30-44.

Van Gijsegem, F., Toussaint, A. \& Casadaban, M. (1987). Mu as a genetic tool. In Pbage $M u$, pp. 215-250. Edited by N. Symonds, A. Toussaint, P. van de Putte \& M. M. Howe. Cold Spring Harbor, NY: Cold Spring Harbor Laboratory.

Van de Peer, Y. \& De Wachter, R. (1994). TREECon for Windows: a software package for the construction and drawing of evolutionary trees for the Microsoft Windows environment. Oxford University Press 10, 569-570.

Van de Peer, Y., Van den Broeck, I., De Rijk, P. \& De Wachter, R. (1994). Database on the structure of small ribosomal subunit RNA. Nucleic Acids Res 22, 3488-3494.

Van de Peer, Y., Nicolai, S., De Rijk, P. \& De Wachter, R. (1996). Database on the structure of small ribosomal subunit RNA. Nucleic Acids Res 24, 86-91.

Wilmotte, A., Van der Auwera, G. \& De Wachter, R. (1993). Structure of the 16S ribosomal RNA of the thermophilic cyanobacterium Chlorogloeopsis HTF ('Mastigocladus laminosus HTF') strain PCC7518, and phylogenetic analysis. FEBS Lett 317, 96-100.

Wyndham, C., Cashore, A. E., Nakatsu, C. H. \& Peel, M. C. (1994). Catabolic transposons. Biodegradation 5, 323-342.

Zhang, C. \& Holloway, B. W. (1992). Physical and genetic mapping of the cat $A$ region of Pseudomonas aeruginosa. $J$ Gen Microbiol 138, $1097-1107$.

Received 24 November 1996; revised 14 March 1996; accepted 15 August 1996. 